\title{
Conclusion to Part I: The Intersection of Islamic Law and Women's Biology
}

Islamic law rarely penalizes barren women or delegitimizes childless marriages. This is the case despite the fact that hadiths dating from the first centuries of Islam decry such marriages, and despite the economic and social problems that accompanied childlessness. Indeed, in Islamic legal theory women could not even be categorically labeled as infertile from the time they reached menarche until they reached old age. Yet this presumption of fertility did not always match up with either biological likelihood or socially constructed diagnoses. This is not to say that Islamic law was irrelevant to the experiences of medieval Muslim women, nor am I suggesting that legal theory represents the "true" place of women in Islamic societies. Rather, I would argue that it is the mismatch between Islamic legal theory, legal practice, biology, and other sources of cultural expectations that had the greatest impact in defining the situations in which medieval barren women found themselves.

This mismatch is evident on multiple fronts. Even though in hadith-based advice literature, the legal-philosophical literature, and in the more theoretical sections of legal handbooks there are frequent mentions of the idea that reproduction is one of the primary goals of marriage (maqāṣid al-nikāḥ), this goal did not shape the development of laws of marriage. To a remarkable extent, it was a different goal of marriage, that of sexual pleasure, that shaped the law. ${ }^{293}$ It was women's roles as possessors of female sexual desire and as objects of male sexual desire that defined their place when contracting a marriage. A woman's desire for sexual satisfaction, her utility as a sexual object, and her defectiveness if she becomes sexually unavailable to her husband, had far greater legal consequences than her desire for children, her utility as a producer of children, and her defectiveness if she was infertile. For this reason, the lower age limit of marriage was set not at the point when a woman would likely produce children, but rather at the point when she became capable of engaging in sexual intercourse. Similarly, a free woman could demand complete sexual intercourse rather than coitus interruptus (usually) not on the grounds of her right to a child, but rather on the grounds of her right to sexual satisfaction. For both sexes, it was not in-

293 Judith Tucker makes much the same point, with an emphasis on a slightly later historical context. J. Tucker, "Muftīs and Matrimony: Islamic Law and Gender in Ottoman Syria and Palestine,” Islamic Law and Society, 1.3 (1994), 272.

Ә OpenAccess. (C) 2020 Sara Verskin, published by De Gruyter. (cc))BY-NC-ND This work is licensed under the Creative Commons Attribution-NonCommercial-NoDerivatives 4.0 License.

https://doi.org/10.1515/9783110596588-007 
fertility, but rather impotence, which served as legal grounds for marriage annulment.

We see a mismatch between law and biology in the laws pertaining to the 'idda period, the ostensible legal purpose of which was to clarify that a womb is not "occupied" by the offspring of a previous husband. However, the 'idda was measured via menstrual cycles, an imperfect proxy for reproductive capacity. Further muddying the situation was the biological possibility of oligomenorrhea and amenorrhea, which proved disruptive to the legal function of the 'idda period. Moreover, the belief in multi-year-long pregnancies, a belief acknowledged both in law and in society at large, added another dimension to concepts of infertility, reproductive availability, and paternity. Finally, the seemingly straightforward biological facts of menarche, menstruation, conception and pregnancy were complicated by women's abilities to "shape" these facts by concealing them or swearing to their occurrence.

We see a mismatch between the legal and social expectations of the role women ought to play in conveying and enjoying the benefits of familial wealth. All women, both fertile and infertile, had the legal right to inherit and thereby the ability to divert wealth from their birth families, and this was a source of frustration which prompted legal intrigue. For infertile women, the frustrations were all the more palpable because even as they diverted wealth to other families, they did not produce multi-generational networks with them. Katherine Kueny, in her work on motherhood in Islamic thought, suggests that this incapacity was further magnified by the infertile woman's inability to create kinship ties through breastfeeding.

\begin{abstract}
Women who have no infant to breastfeed cannot create an expanded network of blood ties with their own children or others among their family or the community of believers. Without the ability to establish such an expansive network of familial relations, few will inherit from them. In the absence of offspring, the wealth of the family must be transferred laterally rather than linearly, a secondary provision put forth in the Qur'ān that stifles a husband's God-given right to sow his own legacy among future generations. Unmoored, barren women are left adrift in a world organized around kinship ties. ${ }^{294}$
\end{abstract}

Finally, there was a blatant mismatch between legal and social attitudes towards polygamy, and infertility further complexified the situation. In Islamic legal theory, a husband could engage in polygamy without reproach and with an expectation that all wives would receive equal treatment. However, in general practice, women, their families, and their communities frequently went out of their way to

294 Kueny, Conceiving Identities, 158. 
protect women from the perceived evils of polygamy. Infertility, however, was an exception to that generalization. It was often acceptable for men in otherwise monogamous societies to engage in polygamy so as to be able to maintain a relationship with a barren wife, while attempting to nonetheless produce offspring. Women who were given the choice between polygamy and divorce might even view polygamy as the better option.

The result of all these mismatches was that the Islamic legal context provided infertile women and their families with a dizzying array of paths, rather than narrow dictates, within which they could maneuver and strategize. It is certainly the case that there were women whose childlessness rendered them particularly weak and in need of protection, and it is also true that as a result of not recognizing infertility as a source of particular social vulnerability, the legal system had no impetus to put in place safeguards to protect their interests. We also see, however, that there were women who could exploit the flexibility provided by the discrepancies highlighted here so as to secure their own well-being. 
